\title{
The metabolism of $\left[{ }^{75} \mathrm{Se}\right]$ selenomethionine in four women
}

\author{
By NORA M. GRIFFITHS, R. D. H. STEWART AND MARION F. ROBINSON \\ Department of Nutrition and Department of Medicine, \\ University of Otago, Dunedin, New Zealand
}

(Received 30 September I975-Accepted 29 October 1975)

\begin{abstract}
x. The long-term fate of an oral dose of $\left[{ }^{75}\right.$ Se]selenomethionine was studied in four women.
2. Urinary and faecal excretion, respiratory losses and whole-body retention of ${ }^{75}$ Se were measured, and also ${ }^{75} \mathrm{Se}$ turnover in whole body, plasma and erythrocytes during a period of 33-44 weeks.

3. Intestinal absorption of $\left[{ }^{75} \mathrm{Se}\right]$ selenomethionine by the four subjects was $95 \cdot 5-97 \cdot 3 \%$ of the administered dose.

4. Urinary excretion accounted for $6-9 \%$ of absorbed ${ }^{75} \mathrm{Se}$ in the first 2 weeks. No radioactivity was detected in expired air.

5. After the initial 8 weeks during which radioactivity decreased more rapidly, wholebody retention of ${ }^{75} \mathrm{Se}$ decreased exponentially with a half-time of $207-290 \mathrm{~d}$.

6 . Plasma ${ }^{75} \mathrm{Se}$ concentration reached a maximum level $3^{-4} \mathrm{~h}$ after the dose. Transient initial uptake of ${ }^{75} \mathrm{Se}$ in erythrocytes during the first hour was followed by a gradual increase to a maximum concentration at 8-12 weeks.

7. These results are compared with the results of an earlier study of the metabolism of $\left[{ }^{75} \mathrm{Se}\right]$ selenite in two of the same women. ${ }^{75} \mathrm{Se}$ from $\left[{ }^{56} \mathrm{Se}\right]$ selenomethionine was found to be more completely absorbed, had a greater retention and smaller endogenous urinary and faecal losses than ${ }^{75} \mathrm{Se}$ from $\left[{ }^{75} \mathrm{Se}\right]$ selenite, and these differences persisted throughout the experimental period. These findings differed from those obtained in rats in which, after an initial period, ${ }^{75} \mathrm{Se}$ from selenite was metabolized similarly to that from selenomethionine.
\end{abstract}

The unusually low concentration of selenium in the blood of New Zealand residents has stimulated interest in its possible role in human nutrition (Griffiths, 1973; Griffiths \& Thomson, 1974; Watkinson, 1974; Robinson, 1975). Although it is not established that the intake of Se should be increased, information is required about the metabolism of Se in man. The fate of an oral dose of $\left[{ }^{75}\right.$ Se]selenite was studied in three women (Thomson \& Stewart, 1974) and in the present study the fate of an oral dose of $\left[{ }^{75} \mathrm{Se}\right]$ selenomethionine has been studied in four women, of whom two were subjects in the previous experiment.

\section{EXPERIMENTAL}

\section{Procedure}

The subjects $G, R, C$ and $T$ were four women aged $34,26,22$ and 23 years respectively, with a mean height of $\mathrm{I} .63 \mathrm{~m}$ and a mean weight of $60 \mathrm{~kg}$. Subjects $\mathrm{G}$ and $\mathrm{R}$ had also participated in the previous study (Thomson \& Stewart, 1974). While fasting, each received a measured oral dose of approximately $20 \mu \mathrm{Ci}\left[{ }^{75} \mathrm{Se}\right]$ selenomethionine (Radiochemical Centre, Amersham, Bucks., UK) containing less than $2 \mu \mathrm{g} \mathrm{Se}$.

\section{Collection of urine}

In the first $24 \mathrm{~h}$ after the dose of ${ }^{75} \mathrm{Se}$, urine was collected every $\mathrm{I} h$ for $\mathrm{ro} h$, then every $2 \mathrm{~h}$ for a further $6 \mathrm{~h}$ and finally for the remaining $8 \mathrm{~h}$. Subsequently $24 \mathrm{~h}$ 
collections were made daily for the next $13 \mathrm{~d}$, and thereafter once each week for the next 8 weeks, and then once every 2 weeks whenever possible for the remaining 23-34 weeks of the study. Urine samples were collected and the amount of radioactivity was measured as described by Thomson \& Stewart (1974).

Stable Se in each $24 \mathrm{~h}$ urine collection was determined fluorimetrically by a modification of the method of Watkinson ( 1966 ), and urinary excretion of radioactivity after the 2nd week was calculated as previously described (Thomson \& Stewart, 1974).

\section{Collection of faeces}

A gelatin capsule containing $50 \mathrm{mg}$ brilliant blue marker (FD \& C No. I; Bates Chemical Division, Crompton \& Knowles Corporation, Landsdowne, Pa., USA) and $200 \mathrm{mg}$ methyl cellulose (Kempthorne \& Prosser, Dunedin, New Zealand) was swallowed immediately after the ${ }^{75} \mathrm{Se}$ dose, to act as a faecal marker. All individual stools passed by G, R, C and T until days 25, I 5, 44 and I 6 respectively, were collected separately. Thereafter a single faecal sample was obtained weekly or 2-weekly during the $24 \mathrm{~h}$ after the day of each urine collection.

Faeces were collected in weighed, waxed-cardboard containers lined with plastic bags, and radioactivity and stable Se content were measured as previously described (Thomson \& Stewart, r974).

\section{Collection of blood samples}

Blood samples (10-1 $5 \mathrm{ml}$ ) from each subject were collected in heparinized tubes at hourly intervals for $10 \mathrm{~h}$ after the administration of the ${ }^{75} \mathrm{Se}$, then at $12, \mathrm{r} 4$ and $24 \mathrm{~h}$. Samples were then taken daily for $14 \mathrm{~d}$, weekly for 6-8 weeks, and 2-weekly whenever possible for $25-36$ weeks.

Plasma and erythrocytes were separated by centrifugation and the cells washed with physiological saline $(9 \mathrm{~g} \mathrm{NaCl} / 1)$. Radioactivity in $2 \mathrm{ml}$ portions of plasma, erythrocytes and whole blood was measured using an automatic sample counter (Autogamma; Searle Analytical Inc., 200 Nuclear Drive, Des Plaines, Illinois, USA) with a ${ }^{75}$ Se standard.

Stable Se was measured in whole blood at the beginning of the study, as previously described (Griffiths \& Thomson, I974).

\section{Measurement of respiratory excretion}

Expired air from subject $\mathrm{T}$ was collected in Douglas bags for 8-10 min periods on three occasions during the first $9 \mathrm{~h}$ after administration of the ${ }^{75} \mathrm{Se}$ dose. Radioactivity in each filled bag was measured by the method used for whole-body counting, as previously described (Thomson \& Stewart, 1974).

\section{Whole-body counting}

Whole-body radioactivity was determined using the method described by Thomson \& Stewart (1974). These measurements were made on three to five occasions during the first $9 \mathrm{~h}$ after administration of the dose, then daily for $\mathrm{I} 4 \mathrm{~d}$, weekly for 6 weeks, and 2-weekly whenever possible for $25-36$ weeks. 


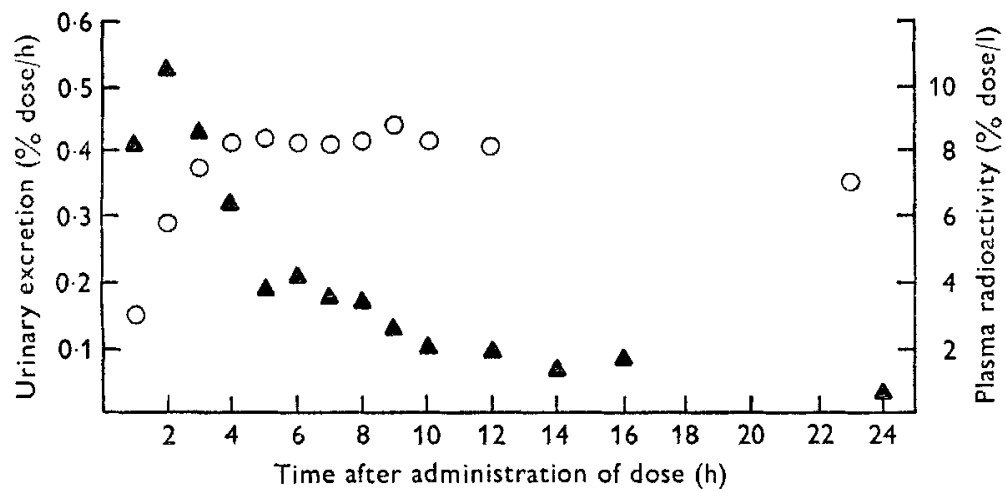

Fig. r. Plasma concentration (O) and urinary excretion (A) of ${ }^{75} \mathrm{Se}$ for subject $\mathrm{R}$ during $24 \mathrm{~h}$ after an oral dose of $\left[{ }^{75} \mathrm{Se}\right]$ selenomethionine. For details of experimental procedures, see pp. $373-4$.

Table I. Absorption, excretion and retention (\% administered dose) of ${ }^{75} \mathrm{Se}$ by four women during the first 2 weeks after oral doses of $\left[{ }^{75} \mathrm{Se}\right]$ selenomethionine*

\begin{tabular}{|c|c|c|c|c|c|c|}
\hline \multirow[b]{3}{*}{ Subject } & \multirow[b]{3}{*}{ Absorption } & \multirow{2}{*}{\multicolumn{3}{|c|}{ Excretion }} & \multicolumn{2}{|c|}{ Retention at day 14} \\
\hline & & & & & From excretion & From whole-body \\
\hline & & Urine & Faeces & Total & measurements & counting \\
\hline G & 97 & $9 \cdot 2$ & $4 \cdot 4$ & 13.6 & 86 & 78 \\
\hline $\mathbf{R}$ & 96 & $8 \cdot 3$ & 5.7 & 14.0 & 86 & 84 \\
\hline $\mathrm{C}$ & 96 & $6 \cdot 0$ & $6 \cdot 1$ & $12 \cdot I$ & 88 & 84 \\
\hline $\mathbf{T}$ & 97 & $6 \cdot 2$ & $4^{\prime} 9$ & $11 \cdot 1$ & 89 & 81 \\
\hline
\end{tabular}

* For details of experimental procedures, see pp. 373-4.

\section{RESULTS}

Urinary excretion of ${ }^{75} \mathrm{Se}$

${ }^{75}$ Se was excreted rapidly in the urine during day $\mathrm{I}$, and the peak excretion rates of $0.42-0.53 \%{ }^{75} \mathrm{Se}$ dose/h occurred within $2 \mathrm{~h}$. The excretion rate then decreased to less than $0.1 \%$ dose $/ \mathrm{h}$ at $\mathrm{I} 2 \mathrm{~h}$ (Fig. I). Urinary losses on day $\mathrm{I}$ were $3.6,3.4,2.6$ and $2.8 \%$ dose for subjects $\mathrm{G}, \mathrm{R}, \mathrm{C}$ and $\mathrm{T}$ respectively. By day 2 urinary losses had decreased to $0.4-0.8 \%$ dose, and by the end of the 2 nd week were $0.2-0.4 \%$ dose $/ \mathrm{d}$. Total urinary excretion in the first $\mathrm{i} 4 \mathrm{~d}$ was (\% dose) 9 for subject $\mathrm{G}, 8$ for subject $R$ and 6 for both subjects $\mathrm{C}$ and $\mathrm{T}$. As nearly all the dose was absorbed, this accounted for $6-9 \%$ of absorbed tracer (Table $x$ ). Urinary excretion of ${ }^{75} \mathrm{Se}$ continued to decrease gradually throughout the study and at 44 weeks the value was approximately $0.08 \%$ dose $/ \mathrm{d}$.

Urinary excretion (mean $\pm \mathrm{SD}$ ) of stable Se was $13 \cdot 2 \pm \mathrm{I} \cdot 7, \mathrm{I} 8 \cdot 9 \pm 3 \cdot 0,8 \cdot 2 \pm \mathrm{I} \cdot 0$ and $\mathrm{I} 2 \cdot \mathrm{I} \pm \mathrm{I} \cdot 5 \mu \mathrm{g} / 24 \mathrm{~h}$ for subjects $\mathrm{G}, \mathrm{R}, \mathrm{C}$ and $\mathrm{T}$ respectively.

\section{Faecal loss and intestinal absorption of ${ }^{75} \mathrm{Se}$}

The cumulative loss of ${ }^{75} \mathrm{Se}$ in faeces is shown in Fig. 2. Faecal radioactivity and the coloured marker both appeared before day 4 although only with subject $R$ did their 


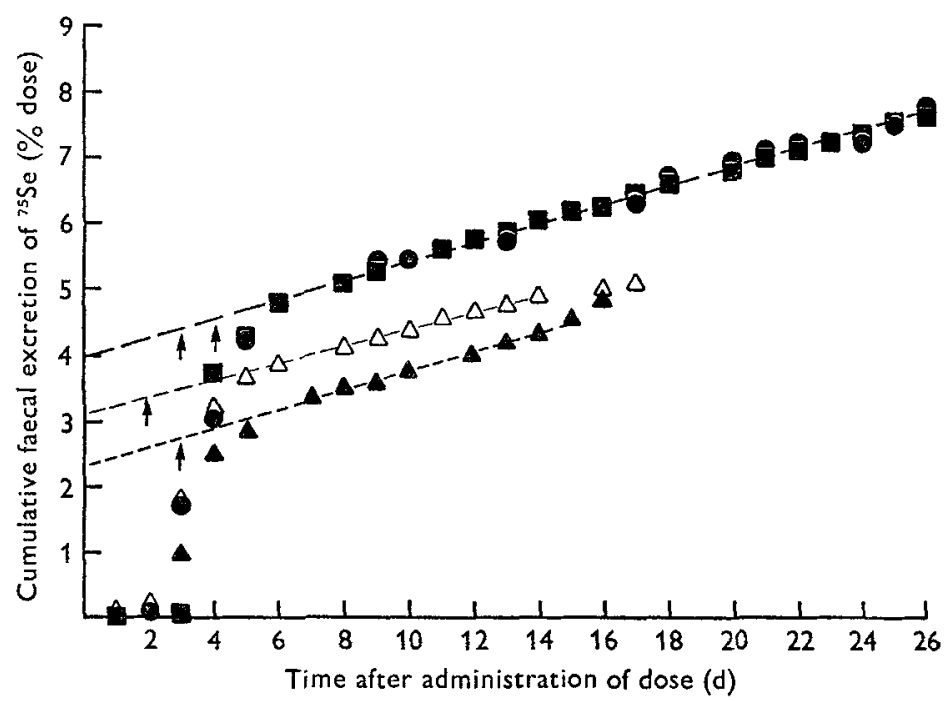

Fig. 2. Cumulative faecal excretion of ${ }^{75} \mathrm{Se}$ in subjects $\mathrm{G}(\mathbf{\Delta}), \mathrm{R}(\boldsymbol{\Theta}), \mathbf{C}(\boldsymbol{D})$, and $\mathrm{T}(\Delta)$ given oral doses of $\left[{ }^{75} \mathrm{Se}\right]$ selenomethionine. $\uparrow$, The first appearance of brilliant blue faecal marker which was given with the ${ }^{75}$ Se. For details of experimental procedures, see p. 374 .

first appearance occur in the same faecal sample. Peak loss of ${ }^{75}$ Se occurred on day 3 or 4 .

Intestinal absorption of ${ }^{75} \mathrm{Se}$ was estimated by plotting cumulative faecal loss during the first 2-3 weeks $v$. time (Lutwak, 1969), and extrapolating back to the time when the marker first appeared, as previously described (Thomson \& Stewart, 1974). By this method it was calculated that $97 \cdot 3,95 \cdot 6,95 \cdot 5$ and $96 \cdot 6 \%$ dose was absorbed by subjects $\mathrm{G}, \mathrm{R}, \mathrm{C}$ and $\mathrm{T}$ respectively, giving a mean absorption of $96.3 \%$ dose (Table I).

Cumulative faecal loss at day I 4 was $4.4,5.7,6 . \mathrm{I}$ and $4.9 \%$ dose for subjects $\mathrm{G}, \mathrm{R}$, $\mathrm{C}$ and $\mathrm{T}$ respectively (Table $\mathrm{r}$ ). Endogenous faecal excretion, estimated as cumulative faecal loss of ${ }^{75} \mathrm{Se}$ minus non-absorbed tracer, was $\mathrm{I} \cdot 3-\mathrm{I} \cdot 7 \%$ dose in the first $14 \mathrm{~d}$ for all subjects. Faecal excretion of ${ }^{75} \mathrm{Se}$ continued to decrease throughout the study and was less than $0.1 \%$ dose/faecal sample by weeks ro-r 9 .

Mean faecal stable Se during the initial collection period of 2 weeks was $8.7,13.4$, 10.7 and $10.2 \mu \mathrm{g} / 24 \mathrm{~h}$ for subjects $\mathrm{G}, \mathrm{R}, \mathrm{C}$ and $\mathrm{T}$ respectively.

\section{Respiratory loss of ${ }^{75} \mathrm{Se}$}

No radioactivity was detected in the Douglas bags containing expired air collected from subject $\mathrm{T}$ during the first $9 \mathrm{~h}$.

\section{Whole-body retention and turnover of ${ }^{75} \mathrm{Se}$}

Total body retention of ${ }^{75}$ Se was estimated directly from whole-body radioactivity measurements and indirectly from estimates of urinary and faecal losses. Whole-body radioactivity measurements obtained at different times on day I varied by as much as $6 \%$ in subjects $\mathrm{G}$ and $\mathrm{T}$, but showed less variation in subjects $\mathrm{R}$ and $\mathrm{C}$. 


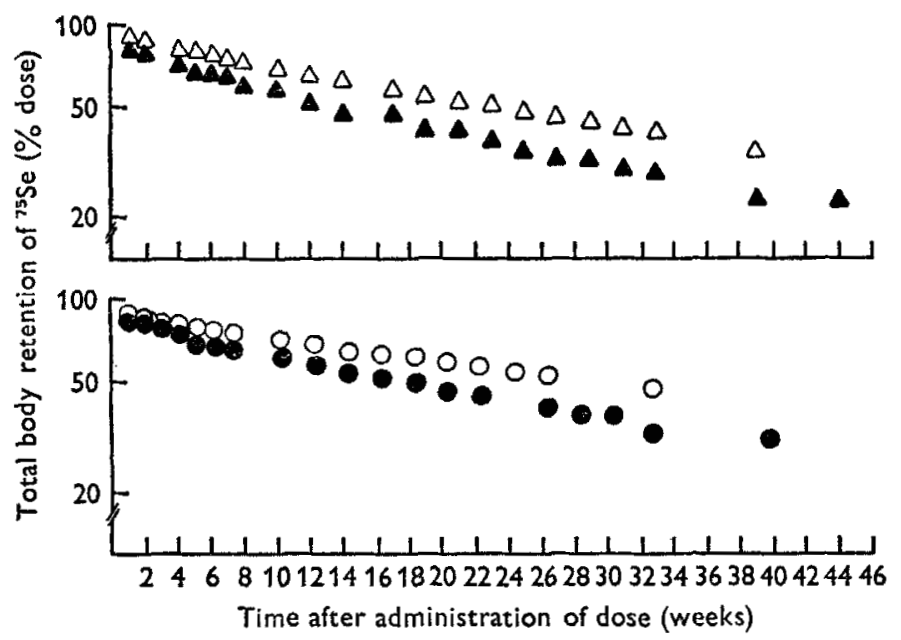

Fig. 3. Total body retention of ${ }^{75} \mathrm{Se}$ in subjects $\mathrm{G}(\Delta, \Delta)$ and $\mathrm{R}(\mathrm{O}, \mathbf{\theta})$ given oral doses of $\left[{ }^{75}\right.$ Se]selenomethionine; $\boldsymbol{\Delta}, \boldsymbol{\theta}$, values estimated from whole-body radioactivity measurements; $\triangle, O$, values estimated from urinary and faecal excretion. For details of experimental procedures, see p. 374 .

Total body retention of ${ }^{75} \mathrm{Se}$ in subjects $\mathrm{G}$ and $\mathrm{R}$ is shown in Fig. 3 . At the end of the 2nd week, values for retention of ${ }^{75}$ Se estimated by whole-body counting were less than those calculated from urinary and faecal excretion by (\% dose) 2 for subject $R$, 4 for subject $\mathrm{C}$ and 8 for both subjects $\mathrm{G}$ and $\mathrm{T}$ (Table $\mathrm{I}$ ). These differences increased to $10-15 \%$ dose for all subjects at the 8 th or roth week, but thereafter the two retention curves were parallel.

Values for total body retention of ${ }^{75} \mathrm{Se}$, estimated from measured urinary and faecal losses, were $90-92 \%$ dose at day 7 and $86-89 \%$ dose at day 14 (Table 1 ). The wholebody retention curves derived from the sum of urine and faecal losses could each be resolved into three exponential components. The first two of these described an initial phase of rapid decrease corresponding with the faecal elimination of unabsorbed tracer and with the urinary and faecal excretion of absorbed but nonutilized ${ }^{75} \mathrm{Se}$. Half-times for retention of ${ }^{75} \mathrm{Se}$ were for subjects $\mathrm{G}, \mathrm{R}, \mathrm{C}$ and $\mathrm{T}$ respectively $\mathrm{I} \cdot 4,2.0, \mathrm{I} \cdot 2$ and $0.4 \mathrm{~d}$ for phase $\mathrm{I}$, and $19, \mathrm{I} 8,5$ and $15 \mathrm{~d}$ for phase 2 . These two phases were followed by a more gradual decrease in radioactivity which also approximated to an exponential decrease, with half-times of 207, 26I, 223 and $290 \mathrm{~d}$ for subjects $G, R, C$ and $T$ respectively. Because of scatter of individual values, the whole-body retention curves derived from whole-body counting could not be analysed in this way.

\section{${ }^{75}$ Se turnover in plasma and erythrocytes}

${ }^{75} \mathrm{Se}$ concentrations in plasma during day $\mathrm{x}$ increased to reach a plateau concentration of $7-10 \%$ dose $/ 1$ in all subjects at $3-4 \mathrm{~h}$ (Fig. I). After $24 \mathrm{~h}$, there was a gradual decrease in plasma ${ }^{75} \mathrm{Se}$ (Fig. 4). The curves for plasma ${ }^{75} \mathrm{Se}$ concentrations $v$. time for all four subjects were resolved into three exponential components. The first two of these represented two rapid phases of decrease in radioactivity and had half-times 


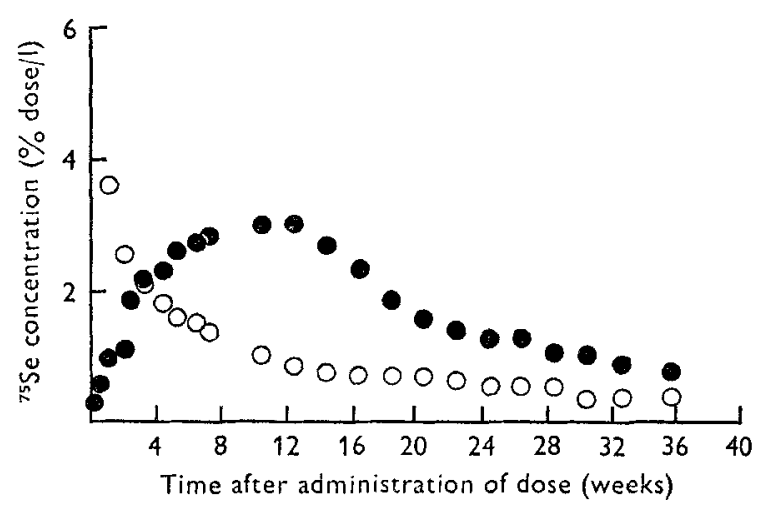

Fig. 4. ${ }^{75} \mathrm{Se}$ concentrations in plasma $(O)$ and erythrocytes $(\odot)$ after day $\mathrm{I}$ for subject $\mathrm{R}$ given an oral dose of $\left[{ }^{75}\right.$ Se]selenomethionine. For details of experimental procedures, see p. 374 .

of $0.8-\mathrm{I}^{\cdot} 4 \mathrm{~d}$ for phase $\mathrm{I}$ and $\mathrm{I} 2-\mathrm{I} 9 \mathrm{~d}$ for phase 2 , and the third component represented a phase of long-term turnover of plasma radioactivity and had half-times of $130-137 \mathrm{~d}$ for subjects $\mathrm{G}, \mathrm{R}$ and $\mathrm{C}$, and $328 \mathrm{~d}$ for subject $\mathrm{T}$.

There was a transient initial uptake of ${ }^{75} \mathrm{Se}$ into erythrocytes, the concentration at I $\mathrm{h}$ being $0.3-0.6 \%$ dose $/ 1$, decreasing to $0.1-0.2 \%$ dose $/ 1$ at $3 \mathrm{~h}$. The levels then remained almost constant until day 2 or 3 , after which they increased steadily to $\mathrm{I} \cdot 6-\mathrm{I} \cdot 8 \%$ dose $/ 1$ at day $\mathrm{I} 4$, and then more gradually to reach a maximum concentration of $2 \cdot 7-3 \cdot 2 \%$ dose $/ 1$ at 8 -I 2 weeks. This was followed by a gradual decrease which continued for the remainder of the experimental period (Fig. 4).

Stable Se concentrations in whole blood were $0.070,0.076,0.055$ and $0.062 \mu \mathrm{g} / \mathrm{ml}$ for subjects $G, R, C$ and $T$ respectively.

\section{DISCUSSION}

This study of four subjects given $\left[{ }^{75} \mathrm{Se}\right]$ selenomethionine was carried out I year after the study of three subjects given [ ${ }^{75}$ Se]selenite (Thornson \& Stewart, 1974). The procedures used in each study were virtually identical, but measurements were continued for $33-44$ weeks after the dose of [ $\left.{ }^{75} \mathrm{Se}\right]$ selenomethionine instead of only ${ }_{16} 6-20$ weeks as after $\left[{ }^{75} \mathrm{Se}\right]$ selenite. In the $\left[{ }^{75} \mathrm{Se}\right]$ selenomethionine study less than $2 \mu \mathrm{g}$ carrier Se was given with the ${ }^{75} \mathrm{Se}$ dose, whereas $10 \mu \mathrm{g}$ Se was given with the $\left[{ }^{75} \mathrm{Se}\right]$ selenite. It is uncertain if this difference has any significance.

The subjects within each study responded similarly and subjects $G$ and $R$ took part in both studies. Thus a comparison of the metabolism of [ $\left.{ }^{75} \mathrm{Se}\right]$ selenomethionine with that of [ ${ }^{75}$ Se]selenite may be made from the measurements in these two women. Both subjects had the low Se status characteristic of New Zealand residents (Griffiths \& Thomson, 1974) and each had a similar Se status for both experiments (Table 2). The slightly higher urinary and faecal output of Se by subject $R$ during the ${ }^{75} \mathrm{Se}$ ]selenomethionine study is attributed to a higher fish content in her diet at this time, and this was reflected in her slightly higher blood Se. The dietary intake, approximately assessed as twice the urinary output, was low compared with published values for intake (Griffiths, I973; Watkinson, 1974). 
Table 2, Blood selenium concentration and mean urinary and faecal Se excretion for subjects $G$ and $R$ during metabolic studies of $\left[{ }^{75}\right.$ Se] selenomethionine (present study) and $\left[{ }^{75}\right.$ Se $]$ selenite (Thomson $\mathscr{E}^{\circ}$ Stewart, 1974)

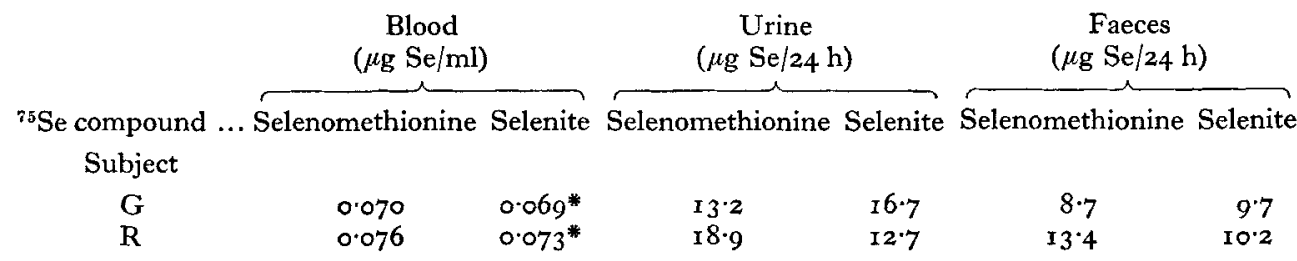

* Thomson \& Stewart, unpublished results.

Table 3. Comparison of absorption (\% administered dose), excretion and retention $\left(\%{ }^{75} \mathrm{Se}\right.$ absorbed) of ${ }^{75}$ Se after oral doses of $\left[{ }^{75}\right.$ Se] selenomethionine (present study) or $\left[{ }^{75}\right.$ Se $]$ selenite (Thomson $\mathcal{E}^{\circ}$ Stewart, 1974), by subjects $G$ and $R$ during the first $14 d$, and by rats during the first $7 d$ (Thomson $\mathscr{\sigma}^{\circ}$ Stewart, 1973)

\begin{tabular}{|c|c|c|c|c|c|c|c|c|}
\hline \multirow[b]{2}{*}{$\begin{array}{r}{ }^{75} \text { Se compound } \\
\text { Subject }\end{array}$} & \multicolumn{2}{|c|}{ Absorption } & \multicolumn{2}{|c|}{ Urinary excretion } & \multicolumn{2}{|c|}{$\begin{array}{l}\text { Faecal excretion } \\
\text { (endogenous) }\end{array}$} & \multicolumn{2}{|c|}{ Retention } \\
\hline & $\begin{array}{l}\text { Seleno- } \\
\text { methionine }\end{array}$ & Selenite & $\begin{array}{c}\text { Seleno- } \\
\text { methionine }\end{array}$ & Selenite & $\begin{array}{l}\text { Seleno- } \\
\text { methionine }\end{array}$ & Selenite & $\begin{array}{l}\text { Seleno- } \\
\text { methionine }\end{array}$ & Selenite \\
\hline $\begin{array}{l}G \\
R\end{array}$ & $\begin{array}{l}97 \\
96\end{array}$ & $\begin{array}{l}70 \\
44\end{array}$ & $\begin{array}{l}9 \\
9\end{array}$ & $\begin{array}{l}20 \\
16\end{array}$ & 2 & $\begin{array}{l}4 \\
6\end{array}$ & $\begin{array}{l}89 \\
90\end{array}$ & $\begin{array}{l}77 \\
79\end{array}$ \\
\hline Rats & 95 & $9 \mathrm{I}$ & 4 & 14 & I I & I3 & 84 & 73 \\
\hline
\end{tabular}

Intestinal absorption of ${ }^{75} \mathrm{Se}$

In contrast to $\left[{ }^{75}\right.$ Se]selenite, $\left[{ }^{75} \mathrm{Se}\right]$ selenomethionine was almost completely absorbed (Table 3), as it had been in rats (Thomson \& Stewart, 1973). However, the difference between the absorption of selenite and selenomethionine was much greater in the human subjects. Because of this difference, in order to facilitate comparison, values for excretion and retention given in Table 3 have been expressed as a percentage of the ${ }^{75} \mathrm{Se}$ absorbed.

\section{Excretion of ${ }^{75} \mathrm{Se}$}

Rates of urinary excretion of ${ }^{75} \mathrm{Se}$ after the administration of [ ${ }^{75} \mathrm{Se}$ ]selenite were approximately twice those after a dose of $\left[{ }^{75} \mathrm{Se}\right]$ selenomethionine throughout the first I4 d (Table 4 ) with peak rates of excretion for both occurring within $2 \mathrm{~h}$ of the dose. However, the difference between the two compounds gradually became less after 2 weeks.

Previous workers have studied the urinary excretion of ${ }^{75} \mathrm{Se}$ in human subjects after an intravenous dose. However, their results may be compared with those obtained after an oral dose by making allowance for incomplete absorption. In three subjects given [ $\left.{ }^{75} \mathrm{Se}\right]$ selenite with a carrier dose of $\mathrm{x} \cdot 5 \mu \mathrm{g} \mathrm{Se}, 5.5-9.4 \%$ dose was excreted in the urine in the first $24 \mathrm{~h}$ and $\mathrm{r} \cdot 2-2 \cdot 7 \%$ dose in the second $24 \mathrm{~h}$ (Burk, I974). These results are comparable to ours (Table 4). On the other hand Lathrop, Harper \& Malkinson (I968) found 6-I5\% dose in the urine in the first $6 \mathrm{~d}$ after the 
Table 4. Urinary excretion (\% ${ }^{75}$ Se absorbed/d) of ${ }^{75}$ Se by two women during the first ${ }_{14} d$ after oral doses of $\left[{ }^{75}\right.$ Se $]$ selenomethionine (present study) or $\left[{ }^{75} \mathrm{Se}\right]$ selenite (Thomson EO Stewart, 1974)

$\begin{array}{cccc}{ }^{75} \text { Se compound } & \ldots & & \\ \text { Subject } & \begin{array}{c}\text { Period after } \\ \text { dose (d) }\end{array} & & \\ \text { Selenomethionine } & \text { Selenite } \\ \text { G } & \text { I } & 3.7 & 8.7 \\ & 2 & 0.8 & 1.7 \\ 7 & 0.4 & 0.9 \\ \text { R } & \text { I } & 0.3 & 0.5 \\ & \text { I } & 3.5 & 6.3 \\ & 2 & 0.6 & 1.4 \\ 7 & 0.4 & 0.7 \\ & \text { I4 } & 0.4 & 0.6\end{array}$

administration of ${ }^{75}$ Se]selenomethionine containing $7-568 \mu \mathrm{g}$ carrier Se. This was rather more than the urinary excretion of $4-6 \%$ absorbed dose by our subjects in this time. In their study, there was no apparent association between urinary excretion rate and the amount of carrier Se administered. It is possible that the initial metabolism of [ $\left.{ }^{75} \mathrm{Se}\right]$ selenomethionine administered by intravenous injection differs from that of [ ${ }^{75}$ Se] $]$ selenomethionine taken by mouth.

In the first 2 weeks after either $\left[{ }^{75} \mathrm{Se}\right]$ selenite or $\left[{ }^{75} \mathrm{Se}\right]$ selenomethionine, urinary excretion of ${ }^{75}$ Se was greater than endogenous faecal loss by a factor of three to six (Table 3). However, this difference became less, so that after 16 weeks urinary ${ }^{75} \mathrm{Se}$ was about twice faecal ${ }^{75} \mathrm{Se}$ in both studies. Endogenous faecal ${ }^{75} \mathrm{Se}$ was higher after $\left[{ }^{75} \mathrm{Se}\right]$ selenite but the reason for this is unexplained. There is some evidence that endogenous faecal Se might be derived mainly from biliary excretion (Charlesworth, Testa, Pullan \& Torrance, I970), but this has not been confirmed.

As in the $\left[{ }^{75} \mathrm{Se}\right]$ selenite study, respiratory losses after a dose of [ ${ }^{75}$ Se]selenomethionine were trivial for the one subject studied. Burk (I974) reported similar findings after giving very small amounts of radioactivity, but Lathrop et al. (I968) were able to measure about $I \%$ of the dose in the expired air from two subjects after a somewhat larger dose of $\left[{ }^{75} \mathrm{Se}\right]$ selenomethionine.

\section{Whole-body retention and turnover of ${ }^{75} \mathrm{Se}$}

Similar differences between whole-body retention, derived directly from wholebody counting and indirectly from the sum of urine and faecal losses, occurred in both studies. As suggested previously (Thomson \& Stewart, 1974) this was most probably caused by inaccuracies in measuring whole-body radioactivity, particularly during the first few days when there would have been considerable changes in the distribution of ${ }^{75} \mathrm{Se}$ in the body.

The retention of absorbed ${ }^{75} \mathrm{Se}$ was greater after [ $\left.{ }^{75} \mathrm{Se}\right]$ selenomethionine $(89-90 \%$ at $14 \mathrm{~d})$ than after $\left[{ }^{75} \mathrm{Se}\right]$ selenite $(76-80 \%$ at $\mathrm{I} 4 \mathrm{~d})$. A similar difference was found in rats, in which $84 \%$ of absorbed ${ }^{75} \mathrm{Se}$ was retained at $7 \mathrm{~d}$ after a dose of [ ${ }^{75}$ Se] selenomethionine and $73 \%$ after a dose of $\left[{ }^{75}\right.$ Se]selenite (Thomson \& Stewart, 1973). 
Table 5. Biological half-times $(d)$ for whole-body retention and plasma concentration of ${ }^{75} \mathrm{Se}$ for two women after oral doses of $\left[{ }^{75} \mathrm{Se}\right]$ selenomethionine (present study) or $\left[{ }^{75} \mathrm{Se}\right]$ selenite (Thomson \& Stewart, 1974)

\begin{tabular}{|c|c|c|c|c|c|}
\hline \multirow{3}{*}{\multicolumn{2}{|c|}{${ }^{75}$ Se compound }} & \multicolumn{4}{|c|}{ Biological half-times } \\
\hline & & \multicolumn{2}{|c|}{ Whole-body retention } & \multicolumn{2}{|c|}{ Plasma concentration } \\
\hline & & Selenomethionine & Selenite & Selenomethionine & Selenite \\
\hline Subject & $\begin{array}{r}\ldots \\
\text { hase }\end{array}$ & & & & \\
\hline \multirow[t]{3}{*}{ G } & I & $x \cdot 4$ & 0.8 & 0.8 & $I \cdot 4$ \\
\hline & 2 & 19 & 7 & 12 & 7 \\
\hline & 3 & 207 & $\log$ & 130 & 69 \\
\hline \multirow[t]{3}{*}{$\mathbf{R}$} & $\mathbf{I}$ & $2 \cdot 0$ & $\mathbf{I} \cdot \mathbf{2}$ & $1 \cdot 4$ & 0.7 \\
\hline & 2 & I8 & 8 & I6 & 5 \\
\hline & 3 & 261 & 96 & 137 & 69 \\
\hline
\end{tabular}

The biological half-times for the three phases of whole-body turnover of ${ }^{75} \mathrm{Se}$ after a dose of $\left.{ }^{75} \mathrm{Se}\right]$ selenomethionine were approximately twice the values obtained after a dose of ${ }^{75}$ Se]selenite (Table 5 ). This was not unexpected for the first two phases in view of the different rates of excretion for $\left.{ }^{75} \mathrm{Se}\right]$ selenomethionine and $\left[{ }^{75} \mathrm{Se}\right]$ selenite. However, the reason for the slower metabolic turnover and lower excretion in urine and faeces of ${ }^{75} \mathrm{Se}$ incorporated into the long-term body pool after a dose of [55Se]selenomethionine is not clear. As indicated previously, there have been considerable differences in reported turnover rates of this long-term Se pool after administration of either $\left[{ }^{75} \mathrm{Se}\right]$ selenite or $\left[{ }^{75} \mathrm{Se}\right]$ selenomethionine (Thomson \& Stewart, 1974). Our finding of a difference between the utilization of the two chemical forms in humans is in contrast to the results obtained in rats, in which ${ }^{75} \mathrm{Se}$, whether from ${ }^{75} \mathrm{Se}$-labelled selenomethionine, selenite, selenocystine or endogenously-labelled rabbit kidney, was apparently incorporated into the same long-term metabolic pool (Thomson \& Stewart, I973; Thomson, Robinson, Stewart \& Robinson, 1975; Thomson, Stewart \& Robinson, I975).

\section{${ }^{75}$ Se turnover in plasma}

Plasma ${ }^{75} \mathrm{Se}$ concentration reached a maximum $3-4 \mathrm{~h}$ after a dose of $\left[{ }^{75} \mathrm{Se}\right]$ selenomethionine, about $4^{-8} \mathrm{~h}$ sooner than after $\left[{ }^{75} \mathrm{Se}\right]$ selenite. It has been reported for [ $\left.{ }^{75} \mathrm{Se}\right]$ selenomethionine (Awwad, Potchen, Adelstein \& Dealy, 1966; Lathrop, Johnston, Blau \& Rothschild, 1972; Stähelin, 1975) and for [ ${ }^{75}$ Se]selenite (Burk, 1974) that ${ }^{75} \mathrm{Se}$ was taken up rapidly by the liver and returned to plasma in a protein-bound form. The results of our studies suggested that this happened more readily after a dose of $\left[{ }^{75} \mathrm{Se}\right]$ selenomethionine because the urinary excretion of ${ }^{75} \mathrm{Se}$ was less than after a dose of $\left[{ }^{75} \mathrm{Se}\right]$ selenite and the peak plasma level was reached earlier.

Whether ${ }^{75} \mathrm{Se}$ from $\left[{ }^{75} \mathrm{Se}\right]$ selenomethionine or from $\left[{ }^{75} \mathrm{Se}\right]$ selenite is incorporated into the same proteins is, as yet, uncertain. In rats, this seems most likely (Millar, Gardiner \& Sheppard, I973) but Burk (1974) found some differences between man and rats in the metabolism of $\left[{ }^{75} \mathrm{Se}\right]$ selenite. In our studies, the longer biological 
half-times for ${ }^{75} \mathrm{Se}$ in plasma after giving [ $\left.{ }^{75} \mathrm{Se}\right]$ selenomethionine (Table 5 ) indicate a slower turnover in man of Se given in this chemical form.

\section{${ }^{75}$ Se turnover in erythrocytes}

Temporary small peaks in erythrocyte ${ }^{75} \mathrm{Se}$ occurred in the first hour at the time predicted by Burk (1974), from his measurements of blood and plasma, for 'formed element ${ }^{75} \mathrm{Se}$.' Thereafter, ${ }^{75} \mathrm{Se}$ from $\left[{ }^{75} \mathrm{Se}\right]$ selenomethionine was steadily incorporated into erythrocytes during a period of 8-12 weeks. The more gradual decrease in erythrocyte ${ }^{75} \mathrm{Se}$ in our studies in comparison with that found by Penner (1966), together with the significant amounts of radioactivity persisting in erythrocytes at $3^{6}$ weeks, indicated that considerable re-utilization of ${ }^{75} \mathrm{Se}$ had occurred.

\section{Se metabolism in man}

The present study was undertaken to complement our previous study of the metabolism of [ ${ }^{75}$ Se]selenite in women (Thomson \& Stewart, 1974) and our studies of Se metabolism in rats (Thomson \& Stewart, I973; Thomson, Robinson et al. 1975; Thomson, Stewart et al. 1975). Differences were found between the fate of ${ }^{75} \mathrm{Se}$ given as $\left[{ }^{75} \mathrm{Se}\right]$ selenomethionine or as $\left[{ }^{75} \mathrm{Se}\right]$ selenite in both man and rats. ${ }^{75} \mathrm{Se}$ from $\left[{ }^{75} \mathrm{Se}\right]$ selenomethionine was incorporated more efficiently into body tissues and in man had a slower turnover than that from $\left[{ }^{75}\right.$ Se]selenite. It seems likely, therefore, that selenomethionine, or food Se in a form that produces selenomethionine after digestion, would prove more effective than selenite in improving a low Se status or in correcting Se deficiency in man. This question is presently being studied.

We are particularly grateful to Miss Clare Casey, Dr Christine Thomson and Miss Mary Taylor for their willing cooperation and assistance as subjects, and to Miss Gaylene Friend for technical assistance. This study was supported by the Medical Research Council of New Zealand.

\section{REFERENCES}

Awwad, H. K., Potchen, E. J., Adelstein, S. J. \& Dealy, J. B. Jr (Ig66). Metabolism r5, 626. Burk, R. F. (1974). Biochim. biophys. Acta 372, 255.

Charlesworth, D., Testa, H. J., Pullan, B. R. \& Torrance, B. (1970). Br. F. Surg. 57, 41 3.

Griffiths, N. M. (I973). Proc. Univ. Otago med. Sch. 5I, 8.

Griffiths, N. M. \& Thomson, C. D. (1974). N.Z. med. F. 80, 199.

Lathrop, K. A., Harper, P. V.\& Malkinson, F. D. (1968). In Radioaktive Isotope in Klinik und Forschung, vol. 8, p. 436 [K. Fellinger and R. Höfer, editors]. Munich: Urban and Schwarzenberg.

Lathrop, K. A., Johnston, R. E., Blau, M. \& Rothschild, E. O. (1972). F. nucl. Med. r3, Suppl. 6, 7. Lutwak, L. (1969). Am. F. clin. Nutr. 22, 77ı.

Millar, K. R., Gardiner, M. A. \& Sheppard, A. D. (1973). N.Z. $\mathscr{f l}$ agric. Res. I6, I 5.

Penner, J. A. (1966). F. Lab. clin. Med. 67, 427.

Robinson, M. F. (1975). The Moonstone: More About Selenium, p. I3. Palmerston North, New Zealand: The Nutrition Society of New Zealand.

Stähelin, H. B. (1975). Metabolism 24, 505.

Thomson, C. D., Robinson, B. A., Stewart, R. D. H. \& Robinson, M. F. (1975). Br. F. Nutr. 34, 501.

Thomson, C. D. \& Stewart, R. D. H. (1973). Br. F. Nutr. 30, I39.

Thomson, C. D. \& Stewart, R. D. H. (1974). Br. F. Nutr. 32, 47.

Thomson, C. D., Stewart, R. D. H. \& Robinson, M. F. (1975). Br. F. Nutr. 33, 45.

Watkinson, J. H. (1966). Analyt. Chem. 38, 92.

Watkinson, J. H. (1974). N.Z. med. F. 80, 202. 